\title{
AN OLD MASTER
}

Il n'y a rien qui soit si nécessaire aux hommes que la danse. . . Tous les malheurs des hommes, toth les revers funestes dont les histoires sont remplies, les bévues des politiques, les manquements des grands capitaines, tout cela n'est venu que faute de savoir danser.

Thear may perhaps be some people who are hardly prepared to accept this as a universal truth. They may even go so far as to think that the artist who seys this cannot be a real character at sll, but is a creation of Molière's own. As to the truth of the sentiment, I do not feel myself in a position to judge, though from what I have observed, I should be inclined to say that many worse reasons have been given before now as excuse for les bevues des politiques; but as to the reslity of the personsge, I can only say that it has been my privilege to learn from one who was the very re-incarnation of M. Jourdain's famous teacher. Centuries and environment had altered him, it is true, but in his sense of the seriousness and the necessity of his vocation, he was essentially the same man. The old master was Molière's maitre d danser soen through the medium of a cathedral city. The wig has changed to sparse iron grey locks, the brave satin coat and raffes, the knee breeches, the silk stockings, are replaced by a suit of clerical black broadcloth, white shirt front, black tie. The buckled shoes have become cloth boots, close fitting, elestic sided, with shining leather tips.

Molière's maitre d danser was a goad fellow and a true artist. His vocation was all in all to him, but he took it gaily. He might be a genial "bbe of the dancing cult; the old master was its archdeacon. I do not suppose it ever crossed his mind that dancing was an amusement, nor, for that matter, an education for the human frame generally. His motto was: " Look after the feet, and the rest may take care of itself." His interest began and ended in the eract pointing of the toe, the exact angle of the foot-in the first, second, or third position. The old master was very tall, rather spare, slightly stooping; he had a most reverend appearance, an impassive countenance; $I$ never remember seeing him smile. He spoke only of his art, and of his bees; for he kept bees in the small garden, at the back of his austere little old brick house. He taught dancing steps as works of art in themselves, not as means to an end; and I do not think we often had an idea that 
the elaborately described and dissected movements we slowly learnt had any connection with each other or with any dence as a whole.

In learning a step, we were first shown it by the old master, the cloth boots describing it to us, on the red-patterned drugget, with a mathematical precision. About an hour would then be spent in acquiring perhaps one-half of it, the exact position of each part of the foot during each part of the step being mapped out by the stars on the dragget. Then the moment arrived for doing it " with the music." The old master raised his little fiddle to his chip and played a little pizzicato tune, dancing himself the while with fitting gravity. The chaos always resulting from first attempts with the tune he took patiently-with a kind of bitter resignation. He would sometimes ejaculate, if one pupil crossed to the wrong side or another forgot to turn out both feet equally, " Now she's off!" or, "There's a pretty toe!" But, as a rule, he only implied that he thought something was very wrong; though " least said soonest. mended," and the only thing to be done was to begin all over again, and practise each minute detail without loss of time. I do not know where he got his little tunes, or whether he invented them as he went along; I never heard any others like them, and they all had the same staid and practical quality. He had a violin bow, but that was chiefly employed in pointing out the exact spot on the carpet where the toe and the heel should be at a given time; I do not think he often used it for playing the violin. He was always entirely engrossed with his lesson and expected us to be the same; but wo were a small class of stupid, well-behaved children, without the least taste or aptitude for tho dance, as it was then presented to us.

The class was held at his own house in the parlour carpeted with its red and grey drugget, and the rest of the furniture pushed out of the way, the only other object I remember being a cluster of ivory white skeleton leaves under a glass shade on a small round table. Besides these private lessons and public classes-the weekly services of his serious cult-the old master officiated at the festivals, in the shape of annual balls held at the time of the sutumn Assizes. There he might be seon as inaster of the ceremonies, in his black broadcloth and his cloth boots and his large white gloves, greeting each arrival with a bow and, when the dancing began, standing at the top of the room with his feet elaborately tarned ont, in the first position, and lending his countenance to the proceedings. He taught everybody. All the company were past pupils, or parents of present ones. Everybody knew him, he was us much a part of the festivities as the room itself.

The balls were his well-earned " benefit." I dn not know how he endured the sight of ballroom dancing, even though his was the day of vol. II 
quidrilles and slow valsing and the Lancers sedately performed. If he could have seen the developments in dancing to-day-the enthusiasms for the Russian ballet, the activities of the Folk Dance Society-what would hare happened to him? His dearest convictions would have been assailed, and to see his own pupils recognising such false shrines would have taken away his belief in human nature. The pagan origin of the folk-dances he would have accepted without question, for he would have been in the position of a true believer confronted with idolatry

His successors who train the present generation in the cathedral city teach, according to advertisement-

Grace Culture, Rhythmic, Mime, and Ballet Dancing, Side and Centre Practice, Steps of Elevation, Enchantments, Skipping a speciality;

but there will never be a teacher of them all, who will be so wrapped up in his work, as the old master--dancing master to all the children in the county-with his cloth boots, and his red-patterned drugget, and his little fiddle under his chin.

Priscilla Wyatt-Evgkll.

Messrs. W. Heffer and Sons, Ltd., Cambridge, have in the press a volume entitled The Lover's Tasks and Five Other Plays, by Lady Frances Darwin, with an introduction by Mr. Cecil Sharp. These plays are all concerned with the life of country people, and they are in some slight degree based on the folk songs of England. They are not written in dialect, but show an understanding of the thoughts and speech of country people. They have already been acted by village players of many counties. 